\title{
An Examination of Performance Measurement Prospects on the Fourth Industrial Revolution in the Nigerian Selected Public Sector Agencies
}

\author{
Opeyemi Kehinde Akinniyi ${ }^{1}$, Oluwatoyin Muse Johnson Popoola ${ }^{\star 2}$, Chukwuwuike Nathan \\ Amadi ${ }^{1}$ \\ 1 University of Maiduguri, Nigeria \\ 2 Tunku Puteri Intan Safinaz School of Accountancy, College of Business, Universiti Utara Malaysia, \\ Malaysia
}

\begin{abstract}
Performance measurement in public sector organisations has engendered concern of both practitioners and academia. In an emerging economy like Nigeria, technological breakthroughs like the fourth industrial revolution as a mechanism for enhanced performance has further excited concerns for performance measurement. Literature acknowledged that a proper measurement of performance is the base for improving the quality of public goods and services. As such, this study seeks to examine the prospects of performance measurement in the era of IR 4.0 using an exploratory multiple case study research design. Interview method to gather primary data on the phenomenon of IR 4.0 and performance measurement across ten Ministries, Departments, and Agencies (MDAs) situated in the Federal Capital Territory of Nigeria was adopted. Interview results show that though there were persons designated as management accountants, the management accounting function is performed through the accounting department. The study also observed that the internet, digitisation, broadband, and human-computer interface as aspects of IR 4.0 recorded "good" scores. However, Artificial Intelligence (AI), which is an essential attribute of IR 4.0, had inconsistent ratings. This can be attributed to the low level of awareness of the phenomenon of IR 4.0 its numerous facets which can be deployed, such that performance of typical public sector organisations ranked or measured on vale satisfaction of beneficiaries rather than target figures and annual employee appraisal. A strong political will of administrators of the sampled MDA was identified as an essential factor for fully adopting what IR 4.0 has to offer.
\end{abstract}

Keywords: Performance measurement, the fourth industrial revolution, public sector, emerging economies, Nigeria.

JEL Classification: M40, M41, M49, H83

Paper Type: Research

*Corresponding author: E-mail: popoola@uum.edu.my 


\section{INTRODUCTION}

Management accounting is a field of the accounting philosophy concerned with providing the information needed for decision making within a business organisation (Drury, 1994). The Institute of Cost and Management Accountants (ICMA), London, defines Management Accounting as: "the application of professional knowledge and skill in the preparation of accounting information in such a way as to assist management in the formulation of policies and the planning and control of the operation of the undertakings." Similarly, the American Accounting Association describes the phenomenon of management accounting as "methods and concepts necessary for effective planning for choosing among alternative business actions and for control through the evaluation and interpretation of performances." However, the Institute of Chartered Accountants of Nigeria (ICAN) is yet to contribute its definition of management accounting. Though the definition provided by the American Accounting Association improves upon the British definition by introducing the concept of performance, however, the two definitions suggest that management accounting function is a support function.

Over the years, management accounting has evolved from being a support function to being a symbiotic element for ensuring optimisation of organisational potentials (Caicedo, Mårtensson \& Hallström, 2018). This approach to Management accounting function seeks to redefine management accounting as a function needed for securing the going concern of organisations. It can, therefore, be suggested that management accounting function will typically be performed by a management accountant using suitable management accounting techniques depending on prevailing environmental situations. Though, the nexus of the management accounting can be traced to the private sector where managers acting as agents to the principals seek to secure their position by ensuring organisational performance synchronises with expectations of business owners. Prior literature informed some countries of the world have vigorously sought after replicating private sector management accounting functions in their public sector organisations using terms like New Public Management (Hood, 1995, Cosimato, Torre \& Troisi, 2015, Caicedo et al., 2018). The "public sector" is a term which describes a system of organisations managing and using State resources to provide public goods (Smalskys, 2010), which are either not under any competition or are accessible to every individual (Balaboniené \& Večerskienè 2015). However, the major problem with this entity hinged on performance measurement, which allows for evaluating the present to improve the future value provided to the populace (Balabonienè \& Večerskienè 2015).

The essentials for the re-branding in the public sector is to improve performance to satisfy stakeholders. It is not likely that performance can be enhanced unless it can be adequately measured. As such, Performance measurement in the public sector from a management accounting perspective is gradually gaining more attention. In particular, the public sector version of the balanced scorecard (Hafner, 1998; Wilson, Hagarty \& Gauthier, 2004) can be perceived as a groundbreaking development. Despite the success stories of the balanced scorecard in performance management, there is an imbalance between demand and supply of performance information in developing countries (Mimba, Jan van Helden, \& Tillema, 2007). This presupposes that performance information, which is the precipitate of performance measurement in developing countries, still requires the attention of researchers.

In the wake of the fourth industrial revolution, it becomes imperative to review the status of performance measurement in typical public sector organisations in an emerging 
economy like Nigeria because performance measurement is an essential ingredient for achieving organisational success (Wilson, Hagarty, \& Gauthier 2004). In Nigeria, the function of the public sector is performed at three levels; federal, state, and local government; through ministries, departments, and agencies (MDA). This sector of the economy has been known to suffer from its inability to match the input with output, a very fundamental principle of financial accounting for evaluating performance in private sector organisations. Consequently, there is a need to re-evaluate performance measurement practices in government agencies and parastatals of emerging economies like Nigeria at a time when globalisation and the fourth industrial revolution is becoming part of everyday life.

According to Xu, David and Kim (2018), fourth industrial revolution (IR 4.0) is a term coined by Klaus Schwab, founder and executive chairman of the World Economic Forum, which describes a world where individuals move between digital domains and offline reality with the use of connected technology to facilitate and manage their lives. Though this phenomenon sought to enhance the productivity of manufacturing businesses (Boer, Diaz \& Leurent, 2018), it has gradually found its way into public sector functions (Badimo, 2018). Characterised by artificial intelligence (Al), Internet of Things (loT), Analytical power, 3D printers and genetic engineering (Boer et al., 2018 Badimo, 2018), IR 4.0 has implications for public sector performance measurement in an emerging economy like Nigeria. However, the success of IR 4.0 with regards to public sector depends upon; strength of broad bands, reliability of electricity, digitisation, human-computer interface, Egovernment and E-governance (Balkaran, nd). As motivation, this study seeks to achieve the following objectives:

1. To examine the nature of existing performance measurement practices in typical government agencies in Nigeria.

2. To explore the level of awareness of IR 4.0 among typical government agencies in Nigeria.

3. To identify the status of parameters required for a successful transition into IR 4.0 among selected government agencies.

4. To investigate the level of willingness to transit to IR 4.0 with regards to performance measurement in selected government agencies.

\section{Performance Measurement in Public Sector Entities}

From the definition of management accounting offered by the American Accounting Association (AAA), it can be deduced that performance measurement is imperative for achieving organisational success. According to Upadhaya, Munir, and Blount (2014), performance measurement is a process of collecting, analysing, and reporting information regarding the performance of an individual, group, organisation, system or component. It has also been recognised as a process concerned with evaluating how well organisations are directed, controlled, and the value such organisations deliver for customers and other stakeholders (Moullin, 2002).

As a critical component of management accounting (Cuganesam \& Foreman, 2012), performance measurement has a strong relationship with organisational excellence (Moullin, 2007). The performance measurement in public sector organisations has dire consequences and implications. The rationale behind this statement associate with efficient and effective performance measurement practices, which have implications for organisational effectiveness. As a catalyst for new public management, performance measurement results, can be used for holding government accountable for the use of 
available resources (Hood, 1991; Poister, 2003). The continued role of foreign donor government and agencies in the governance of emerging economies like Nigeria has raised continued concerns for performance measurement. Performance measurement results will provide needed information required for determining whether or not desired results of these external entities are undergoing an achievable or attainable status. Furthermore, ability to measure performance will enable the populace to evaluate as well as managers of government agencies determine areas that need improvement, particularly at a time when industrial action appears to be an instrument of dissatisfied employees of government agencies.

Re-emphasising the view of Steven Van de Walle (2007), Ruzita, Azhar and Abu Hasan (2012) posit that performance measurement in public sector organisations is more of a conceptual issue than a philosophical issue. Based on their viewpoint, objectives may lack clear definition and can as well be conflicting among different government agencies. As such, in many emerging countries budget figures serve as a more precise measure of performance (Ghiasi, 2013).

In the public sector of Nigeria, organisational performance is often based on the extent to which budget figures are met. In contrast, the performance of employees is naturally measured on the bases of educational qualification and years of working experience (nonacademic based employees). Performance measurement mechanisms have been described using different nomenclature over the years. Notable ones include performance measurement matrix (Keegan 1989), balanced scorecard (Kaplan \& Norton, 1992), the Cambridge performance measurement system design process (Neely, Mills, Gregory, Richards, Platts \& Baine, 1996), and integrated performance measuring system model (Bititci 1997) performance prism (Neely and Adams, 2001). All these mechanisms have tried to avoid over-reliance on financial details. According to Hyland, Ferrer, Santa, and Bretherton (nd), these mechanisms will not yield the desired result if there is no feedback. Feedback represents information from consumers of public goods and services as well as employees within the public sector organisations concerning the level of satisfaction as well as identification of areas of improvement. There is no doubt that the feedback mechanism can be enhanced with appropriate information technology.

\section{The Fourth Industrial Revolution and Performance of Public Sector Organizations}

The advent of new technologies now enables citizens to express their opinions through social networks such as Facebook, WhatsApp, Twitter and other online platforms which are fundamental in facilitating e-participation, thereby, enhancing the social accountability of governments (Shava \& Hofisi, 2017). Through increasingly powerful computing devices and networks, digital services, and mobile devices, IR 4.0 has become a reality for people around the world (Badimo 2018). The internet and social media will no doubt make the feedback requirement of performance measurement prompt. For public sector organisations, IR 4.0 holds many benefits, though there must be adequate regulation to protect and preserve data (Jarrar 2017).

Some of the implications of IR 4.0 for performance measurement in the public sector of a developing economy like Nigeria are as follows;

a) Performance of employees within government agencies will be based on the level of satisfaction of the person served rather than the number of years worked.

b) Employee appraisal will be more objective because the same parameters will be applied in organisations that have everyday operations. 
c) Rather than using budget figures as a measure of organisational performance, value enjoyed by stakeholders using feedbacks from polls on social networks will be more appropriate.

d) There must be trained individuals with competence in using performance measurement results to educate policymakers who most often are not management accountants.

e) There must be a political will.

f) There must be an enabling working environment in terms of infrastructure and laws that will facilitate the functioning of elements of IR 4.0.

\section{Method}

This study adopted an exploratory multiple case study research design. This design Research Design is considered appropriate because it allows carrying out an in-depth evaluation of existing performance measurement practices, level of awareness of IR 4.0 as well as to assess these concepts within the realms of management accounting in selected public sector organisations of Nigeria. According to Zach (2006), the multiplecase studies design, offers researchers a proven tool for achieving a deep understanding of a specific phenomenon.

Some federal agencies were selected for this study because; in Nigeria, the federal civil service appears to dictate the pace for agencies of other tiers of government. The federal civil service is organised around ministries, departments, and agencies (MDAs). The selection of these organisations highlights their significance in respect of government fiscal and monetary policies, education, and financial crimes. The identity of these organisations is undisclosed in this study because of ethical considerations. In these organisations, persons in managerial positions were considered appropriate. The respondents were identified using snowballing. This is because of the nature of these organisations. Subsequently, access to the sample group was gained through personal phone calls. Twenty persons were initially contacted from among these MDAs. Sixteen of them expressed an initial willingness to participate in the study, although several later withdrew because of scheduling constraints. Eventually, only ten persons in managerial capacity from ten different MDAs were interviewed.

In this study, Yin's (1984) replication logic using literal replication (where the cases are designed to corroborate each other) was adapted to capture descriptive contexts of performance measurement practices and IR 4.0. This study relied on qualitative data generated through interviews and observation of current practices. The interview was conducted via a phone call. Responses gathered from these organisations were used to resolve the objectives designed for this study. The outcome of the interview responses is presented in Table 1.

Table 1. Interview Responses

\begin{tabular}{cll}
\hline Objective & Question(s) Raised & Response Options/ Elements \\
\hline 1 (a) & $\begin{array}{l}\text { Does your organisation have a distinct } \\
\text { office for performing management } \\
\text { accounting function? }\end{array}$ & $\begin{array}{l}\text { a. Yes } \\
\text { b. No }\end{array}$ \\
\cline { 2 - 3 } (b) & $\begin{array}{lll}\text { To what extent are these attributes used in } \\
\text { evaluating the performance of your }\end{array}$ & $\begin{array}{l}\text { a. Percentage of budget completion } \\
\text { organisation? }\end{array}$ \\
& b. The satisfaction of consumers of your \\
& c. Employee appraisal \\
\hline
\end{tabular}




\begin{tabular}{|c|c|c|}
\hline Objective & Question(s) Raised & Response Options/ Elements \\
\hline (c) & $\begin{array}{l}\text { To what extent does your organisation use } \\
\text { advanced information technology such as } \\
\text { social media platforms and webinars to } \\
\text { evaluate the satisfaction of consumers of } \\
\text { your services? }\end{array}$ & $\begin{array}{l}\text { a. Large extent } \\
\text { b. Moderate extent } \\
\text { c. Not at all }\end{array}$ \\
\hline 2 & To what extent are you aware of IR $4.0 ?$ & $\begin{array}{l}\text { a. Not aware } \\
\text { b. A little knowledge } \\
\text { c. Very well aware }\end{array}$ \\
\hline $3(\mathrm{a})$ & $\begin{array}{l}\text { Responding using very good, good, fair, } \\
\text { bad and very bad, what is the status of the } \\
\text { following, in your organisation? }\end{array}$ & $\begin{array}{l}\text { a. Artificial intelligence } \\
\text { b. Internet } \\
\text { c. Strength of broadband } \\
\text { d. Digitisation } \\
\text { e. Human-computer interface }\end{array}$ \\
\hline (b) & $\begin{array}{l}\text { Responding using not at all, little, moderate, } \\
\text { or large; } \\
\text { To what extent does your organisation } \\
\text { reach out to beneficiaries within the } \\
\text { organisation? }\end{array}$ & $\begin{array}{l}\text { a. E-mails } \\
\text { b. Social media platforms } \\
\text { c. Artificial intelligence }\end{array}$ \\
\hline (c) & $\begin{array}{l}\text { To what extent does your organisation } \\
\text { reach out to beneficiaries, not in the } \\
\text { employment of your organisation? }\end{array}$ & $\begin{array}{l}\text { a. E-mails } \\
\text { b. Social media platforms } \\
\text { c. Artificial intelligence }\end{array}$ \\
\hline 4 & $\begin{array}{l}\text { Evidence from literature has shown that IR } \\
4.0 \text { will enable your organisation to appraise } \\
\text { performance based on the level of } \\
\text { satisfaction of beneficiaries of your services. } \\
\text { Thus, to what extent will your organisation } \\
\text { be willing to adopt the use of the elements } \\
\text { of IR } 4.0 \text { identified in } 3 \text { above? }\end{array}$ & $\begin{array}{l}\text { a. Large extent } \\
\text { b. Moderate extent } \\
\text { c. Not likely }\end{array}$ \\
\hline
\end{tabular}

Table 2. Summary of the Outcome of Interview Responses (FIRS)

\begin{tabular}{cll}
\hline No. & Question(s) Raised & Response Options/ Elements \\
\hline 1 & $\begin{array}{l}\text { Does your organisation have a } \\
\text { management accounting function? }\end{array}$ & $\begin{array}{l}\text { a. Yes } \\
\text { b. No }\end{array}$ \\
\hline 2 & $\begin{array}{l}\text { To what extent are these attributes used } \\
\text { in evaluating the performance of your } \\
\text { organisation? }\end{array}$ & $\begin{array}{l}\text { a. Percentage of budget completion } \\
\text { b. Satisfaction of consumers of your services }\end{array}$ \\
& $\begin{array}{l}\text { C. Employee appraisal } \\
\text { Greater emphasis is accorded to Revenue target } \\
\text { collected being a Revenue collection Agency of Fed }\end{array}$ \\
& Govt. than the other parameters listed above.
\end{tabular}

3 To what extent are you aware of 4IR?
a. Not aware
b. A little knowledge
c. Very well aware
$4 \quad$ Responding using very good, good, fair, bad and very bad, what is the status of the following, in your organisation?
a. Artificial intelligence $=$ Good.
b. Internet = Fair
c. Strength of broadband = Fair
d. Digitization $=$ Very good.
e. Human-computer interface $=$ Very good


An Examination of Performance Measurement Prospects on the Fourth Industrial Revolution in the Nigerian Selected Public Sector Agencies

\begin{tabular}{|c|c|c|}
\hline No. & Question(s) Raised & Response Options/ Elements \\
\hline & \multicolumn{2}{|l|}{$\begin{array}{l}\text { Responding using not at all, little, } \\
\text { moderate, or large; }\end{array}$} \\
\hline & $\begin{array}{l}\text { To what extent does your organisation } \\
\text { reach out to beneficiaries within the } \\
\text { organisation? using: }\end{array}$ & $\begin{array}{ll}\text { a. } & \text { E-mails = Large } \\
\text { b. } & \text { Social media platforms }=\text { Large } \\
\text { c. } & \text { Artificial intelligence }=\text { Moderate }\end{array}$ \\
\hline & $\begin{array}{l}\text { To what extent does your organisation } \\
\text { reach out to beneficiaries, not in the } \\
\text { employment of your organisation? using: }\end{array}$ & $\begin{array}{l}\text { a. } \text { E-mails = Large } \\
\text { b. Social media platforms = Large } \\
\text { c. Artificial intelligence }=\text { Moderate }\end{array}$ \\
\hline 5 & $\begin{array}{l}\text { Evidence from literature has shown that } \\
\text { 4IR will enable your organisation to } \\
\text { appraise performance based on the level } \\
\text { of satisfaction of beneficiaries of your } \\
\text { services. Thus to what extent will your } \\
\text { organisation be willing to adopt the use of } \\
\text { the elements of } 4 \text { IR identified in } 4 \text { above? }\end{array}$ & $\begin{array}{l}\text { a. Large extent = Large Extent. } \\
\text { b. Moderate extent } \\
\text { c. Not likely }\end{array}$ \\
\hline
\end{tabular}

Table 3. Summary of the Outcome of Interview Responses (NDIC)

\begin{tabular}{cll}
\hline No. & Question(s) raised & Response options/ Elements \\
\hline 1 & Does your organisation have a management & a. Yes \\
& accounting function? & b. No \\
\hline 2 & To what extent are these attributes used in & a. Percentage of budget completion \\
& evaluating the performance of your & b. Satisfaction of consumers of your services \\
& organisation? & c. Employee appraisal
\end{tabular}

$4 \quad$ Responding using very good, good, fair, bad a. Artificial intelligence =GOOD and very bad, what is the status of the b. Internet =VERY GOOD following, in your organisation? c. Strength of broadband =VERY GOOD

d. $\quad$ Digitisation $=$ VERY GOOD

e. Human-computer interface $=$ VERY GOOD

Responding using not at all, little, moderate, or large;

\begin{tabular}{lll}
\hline To what extent does your organisation & a. & E-mails=LARGE \\
reach out to beneficiaries within the & b. Social media platforms=MODERATE \\
organisation? using: & c. Artificial intelligence =LITTLE
\end{tabular}
organisation? using:

c. Artificial intelligence $=$ LITTLE

\begin{tabular}{lll}
\hline To what extent does your organisation & a. & E-mails= LARGE \\
reach out to beneficiaries, not in the & b. & Social media platforms $=$ LLTTLE \\
employment of your organisation? using: & c. & Artificial intelligence = NOT AT ALL
\end{tabular}

5 Evidence from literature has shown that 4IR will enable your organisation to appraise performance based on the level of satisfaction of beneficiaries of your services.
a. Large extent
b. Moderate extent
c. Not likely

Thus to what extent will your organisation be willing to adopt the use of the elements of 4 IR identified in 4 above? 
Table 4. Summary of the Outcome of Interview Responses

\begin{tabular}{|c|c|c|c|}
\hline No. & Question(s) raised & Response options/ Elements & Frequency \\
\hline 1 & $\begin{array}{l}\text { Does your organisation have an } \\
\text { office for management accounting } \\
\text { functions? }\end{array}$ & $\begin{array}{l}\text { a. Yes } \\
\text { b. No }\end{array}$ & $\begin{array}{l}3 \\
7\end{array}$ \\
\hline 2 & $\begin{array}{l}\text { To what extent are these attributes } \\
\text { used in evaluating the performance } \\
\text { of your organisation? }\end{array}$ & $\begin{array}{l}\text { a. Percentage of budget completion } \\
\text { b. Satisfaction of consumers of your services } \\
\text { c. Employee appraisal }\end{array}$ & $\begin{array}{l}6 \\
1 \\
3\end{array}$ \\
\hline 3 & $\begin{array}{l}\text { To what extent are you aware of } \\
\text { 4IR? }\end{array}$ & $\begin{array}{l}\text { a. Not aware } \\
\text { b. A little knowledge } \\
\text { c. Very well aware }\end{array}$ & $\begin{array}{l}6 \\
3 \\
1\end{array}$ \\
\hline \multirow[t]{4}{*}{4} & $\begin{array}{l}\text { Responding using very good }(\mathrm{Q}) \text {, } \\
\operatorname{good}(\mathrm{R}) \text {, fair }(\mathrm{S}) \text {, bad }(\mathrm{T}) \text { and very } \\
\text { bad }(\mathrm{U}) \text {, what is the status of the } \\
\text { following, in your organisation? }\end{array}$ & $\begin{array}{l}\text { a. Artificial intelligence } \\
\text { b. Internet } \\
\text { c. Strength of broadband } \\
\text { d. Digitisation } \\
\text { e. Human-computer interface }\end{array}$ & $\begin{array}{c}\text { R-10 } \\
\text { Q- 6; S-4 } \\
\text { Q-7; S-2; } \\
\text { T-1 } \\
\text { Q-8; S-2 } \\
\text { Q-9; S-1 }\end{array}$ \\
\hline & $\begin{array}{l}\text { Responding using not at all }(\mathrm{N}) \text {, } \\
\text { little (Lit), moderate (M), or large } \\
\text { (L); }\end{array}$ & & \\
\hline & $\begin{array}{l}\text { To what extent does your } \\
\text { organisation reach out to } \\
\text { beneficiaries within the } \\
\text { organisation? using: }\end{array}$ & $\begin{array}{l}\text { a. E-mails } \\
\text { b. Social media platforms } \\
\text { c. Artificial intelligence }\end{array}$ & $\begin{array}{c}\text { L-10 } \\
\text { Lit-8; M-2 } \\
\text { N-7; M-3 }\end{array}$ \\
\hline & $\begin{array}{l}\text { To what extent does your } \\
\text { organisation reach out to } \\
\text { beneficiaries, not in the } \\
\text { employment of your organisation? } \\
\text { using: }\end{array}$ & $\begin{array}{l}\text { a. E-mails } \\
\text { b. Social media platforms } \\
\text { c. Artificial intelligence }\end{array}$ & $\begin{array}{l}\text { Lit-9; N-1 } \\
\text { N-10 } \\
\mathrm{N}-10\end{array}$ \\
\hline 5 & $\begin{array}{l}\text { Evidence from literature has shown } \\
\text { that } 4 \text { IR will enable your } \\
\text { organisation to appraise } \\
\text { performance based on the level of } \\
\text { satisfaction of beneficiaries of your } \\
\text { services. Thus, to what extent will } \\
\text { your organisation be willing to } \\
\text { adopt the use of the elements of } \\
\text { 4IR identified in } 4 \text { above? }\end{array}$ & $\begin{array}{l}\text { a. Large extent } \\
\text { b. Moderate extent } \\
\text { c. Not likely }\end{array}$ & $\begin{array}{l}7 \\
3 \\
-\end{array}$ \\
\hline
\end{tabular}

\section{Discussions}

Most of the organisations expressed that they practice management accounting. However, they do not have separate offices or personnel performing the management accounting function. As such, performance measurement is performed by the administrative department. With regards to measuring organisational performance, most of the respondents in the financial sector chose identified meeting predetermined target, which is an attribute of budgeting as the basis of evaluating organisational performance. Very few of the organisations sampled identified satisfaction of consumers of their services, while a considerable number of the organisations mentioned employee appraisal as a basis of organisational appraisal. 
Part of the opportunities provided by IR 4.0 no doubt includes the use of advanced technology and social media to evaluate the satisfaction of consumers. With regards to the extent to which social media and webinar are used in appraising satisfaction of consumers of services rendered most of the respondents expressed not at all, with very few indicating a moderate extent.

In resolving objective 2, respondents were asked about their level of awareness of IR 4.0. Very few of the respondents appear to be familiar with the term. Those that were not familiar expressed their organisation was using some aspects of IR 4.0 without actually knowing they were. For objective 3, item A sought to ascertain the extent of usage of essential aspects of IR 4.0, was observed that all the respondents scored artificial intelligence "good." With regards to the internet, broadband, digitisation, and humancomputer interface, most of the respondents scored their organisations very good. This is because most of their operations are done via the internet. A few of the respondents, however, scored their organisation fair for internet and broadband. E-governance was examined based on information flow using items 3B and 3C. All the respondents expressed that e-mail is used to a large extent. At the same time, social media platforms and artificial intelligence were scored moderate. This is wholly inconsistent with the opinion expressed on the status of artificial intelligence in 3A. This may because these organisations are not yet grounded on the use of Artificial intelligence when compared to e-mails and social platforms.

Objective 4, sought to ascertain the willingness of these organisations to adopt the opportunities provided by IR 4.0. Most of the respondents expressed their desire for IR 4.0. However, they expressed that it will require much political will before it can be fully implemented. Besides, there is a need to put in place the appropriate infrastructure such as stable and cost-effective electricity as well as appropriate bandwidth.

\section{Implications of the Study for Practice}

This study has shown that performance measurement in the public sector is an issue of concern based on evidence from the literature. It has also been identified that for public sector organisations to flourish like successful private sector entities, there is a need to have the management accounting function set aside, rather than having it lumped with other accounting functions.

It has been observed that elements of IR 4.0 have not yet been fully integrated into operations of public sector organisations that are the focus of this study. This has implications for improving value creation, policy formulation of government and consequently satisfaction of members of the broader community in Nigeria

The Institute of Chartered Accountants of Nigeria may need to design an IR 4.0 metrics for evaluating the organisational performance of public sector organisations in Nigeria. This is because members of the institute are employees in these organisations.

\section{Summary, Conclusion and Recommendations}

The fourth Industrial Revolution, characterised by highly sophisticated information communication technology, is a reality that is fast spreading around the globe. Consequently, public sector organisations in emerging economies like Nigeria need to up its game, to remain relevant as well as meet the expectations of supporting nations. 
Consequently, this study adopted an exploratory multiple case study research design, to observe the extent to with elements of IR 4.0 are used in performance measurement. This is because performance measurement result is the premise for designing controls that can result in improved service delivery of public sector organisations. As such, the Institute of Chartered Accountants of Nigeria should also contribute to the definition of management accounting. It can be concluded for the views derived from the interview conducted that some aspects of IR 4.0 are being deployed for performance measurement. However, there is still room for improvement.

\section{REFERENCES}

Badimo, H.K. (2018). The Impact of the Fourth Industrial Revolution on Public Service Delivery. Retrieved from https://www.linkedin.com/pulse/impact-fourth-industrial-revolution-public-service-deliverybadimo/

Balabonienè, I. \& Večerskienè, G. (2015). The Aspects of Performance Measurement in the Public Sector Organization. Procedia - Social and Behavioral Sciences, 213 (2015), 314 - 320

Balkaran, S. (nd). The Fourth Industrial Revolution - Its Impact on the South African Public Sector. Retrieved from http://www.academia.edu/22826511/the_fourth_industrial_revolution_its_impact_on the_south_african_public_sector.

Bititci, U.S. Carrie, A.S. \& Mčdevitt, L.G. (1997). Integrated Performance Measurement Systems: A Development Guide International. Journal of Operations \& Production Management, 17(6), 522-535.

Boer, E., Diaz, H.D. \& Leurent, H. (2018). The Fourth Industrial Revolution and the factories of the future. Retrieved from https://www.mckinsey.com/business-functions/operations/our-insights/operationsblog/the-fourth-industrial-revolution-and-the-factories-of-the-future

Caicedo, H.M., Mårtensson, M. \& Hallström, T. K. (2018). The development of the management accountant's role revisited: An example from the Swedish Social Insurance Agency. Financial Accountability \& Management. https://doi.org/10.1111/faam.12156

Cosimato, S., Torre, C. \& Troisi, O. (2015). How to Innovate Management Accounting for Public Sector: An Italian Case Study. Journal of US-China Public Administration, 12(9), 695-705. https://doi.org/10.17265/1548-6591/2015.09.004

Cuganesan S., Foreman J. (2012). Performance Measurement in the Public Sector: Evaluating Performance Measurement and Reporting in Health. In: Gregoriou G.N., Finch N. (eds). Best Practices in Management Accounting. Palgrave Macmillan, London. https://doi.org/10.1057/9780230361553_15

Drury, C. (1994). The Scope of Management Accounting in Costing. Springer, Boston, MA. https://doi.org/10.1007/978-1-4899-6880-7_1

Ghiasi, M. (2013). Performance measurement in the public sector: Budgeting. International Research Journal of Applied and Basic Sciences,7(13), 988-994

Hafner, A.K. (1998). Partnership and performance: The balanced scorecard put to the test at the University of California. Retrieved from http://www.ucop.edu on 22/07/2011.

Hood, C. (1991). A Public Management for All Seasons. Public Administration, 69 (1),3-19. doi10.1111/j.14679299.1991.tb00779.x.

Hood, C. (1995). The New Public Management in the 1980s: Variations on a Theme. Accounting, Organisations and Society, 20 (2/3), 93-109

Hyland, P., Ferrer, M., Santa, R. \& Bretherton, P. (nd). Performance Measurement and Feedback in a Public Sector Program. Retrieved from https://eprints.qut.edu.au/27004/1/27004.pdf

Jarrar, Y. (2017). What is the role of government in the digital age? Retrieved from https://www.weforum.org/agenda/2017/02/role-of-government-digital-age-data/

Kaplan, R.S. \& Norton, D.P. (1992). The Balanced Scorecard - Measures That Drive Performance. Harvard Business Review. (January/February), 71-79.

Keegan, D.P., Eiler, R.G., \& Jones, C.R. (1989). Are Your Performance Measures Obsolete? Management Accounting, (June), 45-50.

Mimba, N. S. H., Jan van Helden, G., \& Tillema, S. (2007). Public sector performance measurement in developing countries: A literature review and research agenda. Journal of Accounting \& Organizational Change, 3(3), 192-208. https://doi.org/10.1108/18325910710820265

Moullin, M. (2007). Performance measurement definitions: Linking performance measurement and organisational excellence. International Journal of Health Care Quality Assurance, 20(3), 181-183. https://doi.org/10.1108/09526860710743327

Moullin, M. (2002). Delivering Excellence in Health and Social Care. Open University Press, Buckingham

Neely, A. \& Adams, C. (2001). The Performance Prism Perspective. Journal of Cost Management, 15(1), 715. 
An Examination of Performance Measurement Prospects on the Fourth Industrial Revolution in the Nigerian Selected Public Sector Agencies

Neely, A., Mills, J., Gregory, M., Richards, H., Platts, K., \& Bourne, M. (1996). Getting the Measure of Your Business, Manufacturing Engineering Group. Cambridge: University of Cambridge.

Poister, T.H. (2003). Measuring Performance in Public and Nonprofit Organisations. San Francisco: JosseyBass.

Ruzita, J., Azhar, H. R. \& Abu Hasan, H. (2012). Performance Measurement Practices Of Public Sectors in Malaysia. Journal of Global Strategic Management, 1(10), 42-56. https://doi.org/10.20460/JGSM.2012615785

Shava, E., \& Hofisi, C. (2017). Challenges and Opportunities for Public Administration in the Fourth Industrial Revolution. African Journal of Public Affairs, 9(9), 203 - 215

Smalskys, V. (2010). Public Policy and Administration. Retrieved from https://www.mruni.eu/en/mokslo_darbai/vpa/archyvas/dwn.php?id=424942

Upadhaya, B., Munir, R., \& Blount, Y. (2014). Association between Performance Measurement Systems and Organisational Effectiveness. International Journal of Operations \& Production Management, 34(7), 22.

Van de Walle, S. (2009). International comparisons of public sector performance: how to move ahead? Public Management Review, 11(1), 39-56.

Wilson, C., Hagarty, D. \& Gauthier, J. (2004). Results using the balanced scorecard in the public sector, Journal of Corporate Real Estate, 6(1), 53-64. https://doi.org/10.1108/14630010410812234

Xu, M., David, M.J. \& Kim, H.S. (2018). The Fourth Industrial Revolution: Opportunities and Challenges. International Journal of Financial Research, 9(2), 90-95.

Yin, R. (1984). Case study research: Design and methods, 1st ed., Beverly Hills, CA: Sage Publishing.

Zach, L. (2006). Using a Multiple-Case Studies Design to Investigate the Information-Seeker Behaviour of Arts Administrators. Lynda, M. Baker (eds.). Research Methods, 55(1), 4-21. 